Conference on Individual Freedom and Social Responsibility

THE tension between society and the individual was emphasized by more than one speaker at the Ethics and Science Conference organised by the British Social Hygiene Council in March this year. This conflict, recurrent in every age, but particularly acute in our own, was felt to be one meriting closer examination than was possible at the time, and for this reason another Ethics and Science Conference has been arranged for Thursday, June 10, wht: the subject will be "Where does Freedom End ?" On one hand, the individual is faced with certain obligations towards the community-obligations which seem to increase in number with the growth of the welfare State. On the other hand, there is the urge to self-expression, which only too often appears to conflict with man's social responsibilities. The need for reconciling these two principles is present in every department of life, but is nowhere more clamant than in the spheres of home and work. The Conference will therefore concentrate on these two aspects of the problem, Canon V. A. Demant, of St. Paul's Cathedral, dealing with the first, and Prof. T. S. Simey, professor of social science in the University of Liverpool, with the second. The Conference will take place in the Livingstone Hall, London, from 2 p.m. until 5.30 p.m., and ample time will be allowed for discussion. Tickets (price 2s. 6d.) and further information may be obtained from the Secretary, British Social Hygiene Council (Dept. S.J.1), Tavistock House North, London, W.C.1.

\section{Conference on the Overseas Territories of Western Europe}

A Studx Conference on the Overseas Territories of Western Europe is to be held in the Indisch Institut, Amsterdam, under the joint auspices of the Allied Circle, Amsterdam, and the British Society for International Understanding, during June 9-12. The purpose of the Conference is to study in their widest aspects the implications for the Overseas Territories of the union which is in process of formation between the countries of Western Europe; to promote mutual understanding of the actual conditions, needs and possibilities of the countries for whose well-being the British, French, Belgian, Netherlands and Portuguese Governments are responsible outside Europe; to learn what steps have been taken or could be taken to develop collaboration between them in the spheres of economics, social welfare and security, and to consider the education of public opinion upon this important subject. Further information ean be obtained from the Secretary, British Society for International Understanding, Benjamin Franklin House, 36 Craven Street, London, W.C.2.

\section{The Night Sky in June}

New moon occurs on June 7 d. 12h. 55m., U.T., and full moon on June 21d. 12h. 54m. The following conjunctions with the moon take place: June 8d. $23 \mathrm{~h} .$, Mercury $4^{\circ}$ S. ; June 9d. 04h., Venus $3^{\circ}$ S. ; June 11d. 17h., Saturn $4^{\circ}$ S.; June 13d. 08h., Mars $4^{\circ} \mathrm{S}$; June 21 d. 0lh., Jupiter $4^{\circ} \mathrm{N}$. In addition to these conjunctions with the moon, Mercury is in conjunction with Venus on June 30d. 19h., Mercury being $1 \cdot 0^{\circ} \mathrm{S}$. Mercury is an evening star at the beginning of the month, but towards the middle of the month is too close to the sun for favourable observation, and is in inferior conjunction on June
24. Venus is conspicuous in the western sky, setting at $22 \mathrm{~h} .35 \mathrm{~m}$. and $21 \mathrm{~h} .10 \mathrm{~m}$. on June 1 and $15 \mathrm{re}-$ spectively, and is in inferior conjunction on June 24. Mars is still visible as an evening star, setting at $0 \mathrm{~h} .48 \mathrm{~m}$. and $23 \mathrm{~h} .15 \mathrm{~m}$. at the beginning and end of the month respectively, and Saturn, which is fairly close to Mars, sets on the corresponding dates shortly after midnight and $22 \mathrm{~h}$. $22 \mathrm{~m}$. respectively. Jupiter, in opposition on June 15 , is visible throughout the night, but is rather low for good observation in northern latitudes. No occultations of stars brighter than magnitude 6 occur in June. Summer solstice occurs on June 2ld. $12 \mathrm{~h}$.

\section{Announcements}

The Right Hon. Sir Stafford Cripps has been elected a fellow of the Royal Society under Statute 12 of the Society, which provides for the recommendation by the Council of persons who "have rendered conspicuous service to the cause of science, or are such that their election would be of signal benefit to the Society".

Prof. E. O. Lawrence, professor of physics and director of the Radiation Laboratory, University of California, Berkeley, has been elected an honorary fellow of the Physical Society.

THE following have been elected officers of the Royal Aeronautical Society for the year 1948-49: President, Dr. H. Roxbee Cox ; Past Presidents, Sir Frederick Handley Page, Sir A. H. Roy Fedden; Vice-Presidents, Sir John Buchanan, Mr. W. G. A. Perring, Mr. N. E. Rowe; Hon. Librarian, Mr. J. E. Hodgson; Hon. Treasurer, Captain C. F. Uwins; Secretary, Captain J. Laurence Pritchard

IN connexion with the next General Assembly of the Union Radio Scientifique Internationale, to be held at Stockholm in July (Nature, May 1, p. 695), Unesco is contributing 3,000 dollars to the travelling expenses of the official members of the Union who will attend the meeting, and another 3,000 dollars to the publication of the report of the General Assembly.

A symposium on "The Geneties of Cancer", organised by the Genetical Society of Great Britain and the British Empire Cancer Campaign, is being held during June 24-25 in London. Among the topics to be discussed are inheritance of cancer in animals; virus- and carcinogen-induced mutations; inheritance of cancer in man. A number of American, Continental and British scientific workers will read papers. The meetings will be open to all interested in the sub. ject. Further particulars can be obtained from Dr.R.R. Race, Lister Institute, Chelsea Bridge Road, S.W.1.

THE Committee of the Challenger Society has received a grant from the Development Fund to assist in paying the expenses of certain oceanographers attending joint meetings arranged by the Society. It is not available for members of Stateaided institutions, nor can it be used for undergraduates. It may be used for others than members of the Challenger Society. Grants from the fund will consist of third-class travelling fare and a daily subsistence allowance. The awarding of grants rests with the Committee of the Challenger Society. The number for one meeting is likely to be limited to five or six. Applications for grants for a meeting to be held at the Fisheries Laboratory, Lowestoft, on July 8 and 9 should be submitted to the Honorary Secretary, Challenger Society, British Museum (Natural History), Cromwell Road, S.W.7, before June 15. 